\title{
ERCC1 Gene
}

National Cancer Institute

\section{Source}

National Cancer Institute. ERCC1 Gene. NCI Thesaurus. Code C20554.

This gene is involved in nucleotide excision repair. 